\title{
CAREER EDUCATION IMPLEMENTATION IN GYMNASIUM FROM THE STUDENTS' POINT OF VIEW
}

\author{
Renata Vaitulionienė \\ Kalvarijos gymnasium, Lithuania \\ E-mail: renvait@gmail.com \\ Dalia Augienè \\ Šiauliai university, Lithuania \\ E-mail: augiene@gmail.com
}

\begin{abstract}
Career planning becomes one of the most important processes in a young man's life, during which a decision is made, influencing his further life. Further work, satisfaction with life, life style, leisure time, social status depends on the career one chooses to pursue. In this process, professional orientation taking place at school, consultation, information, have an important role to play. School must form conditions for all learning students to get career education, professional information and consultation services.

Research aim was to analyse the opinion of final gymnasium class students about career education realisation, the obtained services in the gymnasium. The research object was career education in Lithuanian general education schools (gymnasiums). In the research, a survey strategy was applied, a survey research method in written form (a survey questionnaire). The research was carried out between the months September to December 2018. A total of 200 gymnasium 4th grade students from five biggest municipalities of Marijampole region participated in the research. Questionnaire data analysis was carried out, the research data grouping, generalisation, comparison, a quantitative and qualitative descriptive statistics analysis was conducted. By this research, students'opinion about the use of various events planning the career was ascertained. Students perform various tests, consultations, informational events take place. However, a big part of the respondents think that this information is not sufficient for them, they feel a lack of information and support. Students' expressed expectations are not completely satisfied. Students lack knowledge about study programmes, profession specificity. The biggest part of the students understand the importance of professional career planning for their life quality, however, they lack information on that question. Students have expectations and questions, to which they do not receive answers.
\end{abstract}

Keywords: career education, career choice, career competencies, gymnasium students.

\section{Introduction}

Lithuanian State Education 2013-2022 strategy (2013) foresees that society has to become active, solidary, constantly learning, and every person - open for changes, creative and responsible. Today, career is understood as a lifelong lasting person's learning, self-expression and work path, 
and a successful career - is also an ability to match work, leisure, life in the family and to feel satisfaction with the choice of one's life path. It goes without saying, that a student while still at school should start to prepare for a successful career path, therefore, he has to get support from teachers, career specialists and also from parents. Having support from them, a student has to learn to constructively think about the future: to learn systematically to increase the amount of knowledge, to train abilities, to develop one's competencies, which will help to choose the study direction, professional activity, to plan one's own place in the labour market.

The order of the Minister of Education and Science of the Republic of Lithuania "Due to career education programme" (2014) establishes career education goals, spheres and tasks, career competencies. It is sought that professional information would take place as a system. The aim of the career education programme is to form conditions for the students to develop their career competencies, necessary for successful choice of learning direction, profession and/or work activity, for transition from learning surroundings to the work environment, for further professional development and for lifelong learning. Career education is usually related to a special teaching course, a support making an individual development or career plan, providing information and consultation services in various ways. Career education is a wholeness of consistently applied devices, by which it is sought to develop the person's career planning, implementation and evaluation, i.e., career management competencies. Career competencies comprise four competence spheres: self-cognition (to cognise important personality characteristics for career, to cognise social environment and social roles), career possibility cognition (to find and to effectively use career information, to cognise lifelong learning possibilities, to cognise the changing working world), career planning (to raise life and career aims, to make career decisions, to make and renew the career plan) and career implementation (to apply and improve the most important for career general competencies, to successfully move to another career (learning or work) environment, to effectively search for a job). Career education services, comprising career learning, career consultation, career information, career evaluation, professional activities and work search, have to be a constant and uninterrupted process with respect to the student (General education school and vocational institution students' career education model, 2011)

Professional career choice is one of the most important and responsible choices in a young person's life, however, the research (Juraite, Laužackas, Pukelis, 2003; Pukelis, Garnienė, 2003; Kalinauskaitè, Adaškevičienè, Tarnauskas, Žvirdauskas, 2005; Indrašienė, Rimkevičienė, Gaigalienè, Railienè, Grinytė, 2006; Garnienè, 2006) reveal that final grade students are often not self-determined about the future profession, do not orientate themselves in profession and professional activity world. In Lithuania, still not a sufficient attention is devoted to career education, though youth unemployment increases and already exceeds general unemployment level in the country. Their, especially students', professional consultation and career education demand in the country is not sufficient. Professional consultation specialists are not enough professionally prepared to provide qualitative services, therefore, have an insufficient influence in choosing and further modelling career possibilities (Augienè, Lamanauskas, 2017). Therefore, a chaotic state and episodicity of career education, career information and career consultation services, make students' self-determination, regarding future professional career, heavier. The research showed that differences existed between career self-determined and not determined students according to many personality variables (Pečjak \& Košir, 2007).

Schools must form conditions for all learning students in them to receive career education, professional information and consultation services. Career education services have to provide the responsible school specialists (a psychologist, a social pedagogue), career specialists. Professional orientation specialists at school have to help the student to choose suitable education and occupation possibilities for him and to plan his future job career. Professional orientation at school comprises these services: career education, professional orientation and professional consultation, activity services.

The research object was career education in Lithuanian general education schools (gymnasiums). The research aim was to analyse final gymnasium grade students' opinion in the aspect of career education realisation. 


\section{Research Methodology}

\section{General Research Characteristics}

In the research a survey strategy was applied, the research method was a survey in written form (a questionnaire survey). The research was carried out in the months September to December 2018. A total of 200 gymnasium $4^{\text {th }}$ grade students from five biggest municipalities of Marijampole region participated in the research. The research was regional, the research conclusions were not generalised.

\section{Research Sample}

A total of 200 gymnasium final grade students participated in the research. 40 students from five different gymnasiums (one gymnasium from each municipality) were included in the sample. The questionnaire was fulfilled by 200 gymnasium students: 114 female (57.0\%) and 86 males (43.0\%). The 18- year- old youth, learning in the $4^{\text {th }}$ gymnasium grades, comprise the biggest part of the respondents. These grade students prepare for school-leaving exams therefore, it is natural that both the future teaching institution choice and admission conditions and so on, are actual for them. The biggest part of the students are 18 years old - $166(83.0 \%)$ respondents, 17 - year old - $32(16.0 \%)$ respondents, 16 - year old - $1(0.5 \%)$ respondent and 19 - year old $-1(0.5 \%)$ respondent.

The research was carried out having introduced the respondents with the research aims beforehand, having agreed about the convenient time for them. It was agreed about keeping the confidentiality principle, anonymity was guaranteed concerning the respondents' presented information during the research. The research use and importance were explained to the research participants, seeking to motivate to sincerely participate in the research. During the research, the principles of respect to person's dignity, were taken into consideration. Each research participant was informed about research goals and had the right to independently decide about participation / non participation in the research or withdrawal from it.

\section{Research Instrument and Procedure}

Inquiring the students, a questionnaire survey method was used. In order to carry out the research, a verbal agreement from gymnasium administration was received. Before starting a questionnaire survey, the respondents were introduced to the principle of submitting answers. The respondents had a possibility to mark one of several possible answer variants, possibilities were formed to insert other (personal) remarks, one's own opinion. In the questionnaire survey, it was sought to analyse the following essential parameters:

- Career planning actuality;

- Support providers choosing a career path;

- Activities, helping to make a career choice;

- Information sufficiency making a career choice;

- The activity devoted to career education, professional information and consultation usefulness, students' expectations and demands choosing a profession;

- Factors, having influence on a career choice.

\section{Data Analysis}

Questionnaire data statistical analysis was carried out, research data grouping, generalisation, comparison, a quantitative and qualitative descriptive statistics analysis was conducted. Descriptive statistics measures were applied, i.e., absolute and relative frequencies were calculated. Also, a popularity/significance index was calculated $(0 \leq \mathrm{PI} / \mathrm{SI} \leq 1)$. The more $\mathrm{PI} / \mathrm{SI}$ value was closer to 1 , the more important was the statement, that is, the respondent valued it more. 
The $4^{\text {th }}$ grade gymnasium students were asked, if it was often spoken in the gymnasium about career planning. $40.0 \%$ of all having participated in the survey agreed that it was often spoken about the career planning, $5.0 \%$ of the respondents claimed that it was very often spoken about career planning. $38.0 \%$ of the respondents heard about career planning, however, in their opinion, information was too little. The latter chose the answer that it happened rarely. Thus, one can make an assumption that it is spoken with the students about career planning in the gymnasiums. However, this is not enough, because $14.0 \%$ of the gymnasium students thought, that this was done very rarely, and $3.0 \%$ asserted that they did not receive such services at all.

During the research, it was sought to find out if gymnasium students planned their career, if this question was actual for them. The research results showed that $60.0 \%$ of the respondents planned their career, $24.0 \%$ of the respondents lacked information regarding this question. It is regrettable that $8 \%$ thought that it was too early for them to plan their career, even $8.0 \%$ - did not plan it at all. Taking into consideration that the respondents were gymnasium $4^{\text {th }}$ grade students and in spring were going to take the chosen school leaving exams, their answers make one think that some of them thought irresponsibly about their career choice and their future.

During the survey process, it was analysed who (what people) could help students making a career choice at school, planning their career, who the students could discuss their career plans with. Having analysed the result answers, one can state that $60.0 \%$ of the respondents knew that they could apply to the career education coordinator for support. These students understood the carried-out functions of this position in the gymnasium. $50 \%$ of the respondents relied on their class teacher, and $42.5 \%$ - on a subject teacher. These results allow stating that career education programme is integrated into subjects and into class teachers' activity. Therefore, students know that these teachers can provide them with the necessary information and help them choosing the profession. The research results also showed that the respondents knew that education support specialists could help them on career education questions, i.e., a social pedagogue (27.0\% of the respondents) and a psychologist ( $22.5 \%$ of the respondents). The students indicated a few people each, being able to advise and to help. One can make an assumption that in the education institutions, students know which people they can apply for help making a career choice.

Also, it was sought to ascertain during what activities the information was provided for students about studies, professions or provided another support on career questions. Mostly, the students were provided with information about professions during the meetings organised at school with various profession representatives. $62.5 \%$ of the respondents chose this answer. The necessary information was provided during class hours, $53.5 \%$ of the respondents confirmed this. The students stated that trips to Higher school fair were useful for career education (52.5\% of the respondents), class hours on career planning topics ( $52.5 \%$ of the respondents), and trips to enterprises and institutions $(52.5 \%$ of the respondents). The research results allow stating that students performed self-cognition $(52 \%$ of the respondents) and profession suitability ( $42.0 \%$ of the respondents) tests, which were useful for them and helped to choose the profession. The students pointed out the other useful activities of getting familiar with the professions: meetings with the former students (29.0\% of the respondents), participation in open door days organised by various teaching institutions ( $28.5 \%$ of the respondents), individual consultations (26.0\% of the respondents), meetings with Youth occupation centre representatives (17.0\% of the respondents), profession days project "Jump into parents' clogs" $(5.5 \%$ of the respondents). These results (the event abundance and importance) allow making an assumption, that to organise meetings, to go into open door days and to carry out individual consultations and so on, a responsible person is necessary and specially allotted time for organising and carrying out these activities. Therefore, the consequences of the current situation are (that in some schools there is no, or it is assigned only a small part of the full-time job) - a lack and episodicity of the activities, during which a support is provided for the students choosing a profession.

During the research, it was analysed if the provided information was sufficient for the gymnasium students choosing the profession. It was stated that $17.0 \%$ of the respondents claimed that the provided information about professions was quite sufficient, $39.0 \%$ of the respondents - it was partly sufficient. However, even $40.0 \%$ of the respondents thought that this information was 
not sufficient for them. One can claim that such information is necessary for the students, they have expectations and questions. Evaluating the research results, one can see that students not only wish the information, but also exactly know what information they need. $4.0 \%$ of the respondents answered that they did not know if there was enough information for them about the profession. One can make an assumption that they irresponsibly think about career choice and are not interested in the information provided about professions.

During the research it was analysed what information the respondents lack most of all. The results are presented in Table 1.

Table 1. Information sufficiency choosing a profession.

\begin{tabular}{lcccc}
\hline \multicolumn{1}{c}{ Information characteristics } & Sufficient & Partly sufficient & Insufficient & SI \\
\hline Order of entering higher schools & $95(47.5)$ & $64(32.0)$ & $41(20.5)$ & .64 \\
Personal feature cognition & $71(35.5)$ & $92(46.0)$ & $37(18.5)$ & .59 \\
Profession demand & $58(29.0)$ & $97(48.5)$ & $45(22.5)$ & .53 \\
Profession raised requirements & $65(32.5)$ & $81(40.5)$ & $54(27.0)$ & .53 \\
Further study possibilities & $57(28.5)$ & $90(45.0)$ & $53(26.5)$ & .51 \\
Chosen profession suitability & $47(23.0)$ & $97(48.5)$ & $56(28.0)$ & .48 \\
Employment possibilities & $35(17.5)$ & $105(52.5)$ & $60(30.0)$ & .44 \\
Motivational letter writing & $37(18.5)$ & $79(39.5)$ & $84(42.0)$ & .38 \\
Preparation for an interview with an employer & $25(12.5)$ & $60(30.0)$ & $115(57.5)$ & .37 \\
CV writing rules & $37(18.5)$ & $64(32.0)$ & $99(49.5)$ & .35 \\
\hline
\end{tabular}

The biggest part of the respondents (47.5\%) answered that there was enough information about the order of entering higher schools $(S I=.64)$. One can claim that there was enough information devoted to personal feature cognition $(S I=.59)$, about the profession demand $(S I=.53)$, about profession raised requirements $(S I=.53)$, and further study possibilities $(S I=.53)$. The respondents stated that there was lack of information about $\mathrm{CV}$ writing rules $(S I=.35)$, about the preparation for the conversation with the employer $(S I=.37)$, about motivational letter writing $(S I=.38)$, employment possibilities $(S I=.44)$, information about the chosen profession suitability $(S I=.48)$.

During the research, it was analysed what professional information, consultation, career education activity was the most useful for the students in the gymnasium. The results are presented in Table 2.

Table 2. Career education activity usefulness.

\begin{tabular}{lcccc}
\multicolumn{1}{c}{ Statements } & Agree & Partly agree & Do not agree & SI \\
\hline $\begin{array}{l}\text { Found out what subject exam results would be } \\
\text { necessary in order to study the chosen speciality }\end{array}$ & $116(58.0)$ & $60(30.0)$ & $24(12.0)$ & .73 \\
$\begin{array}{l}\text { Found out about the entrance to vocational institutions } \\
\text { order and raised requirements }\end{array}$ & $94(47.0)$ & $76(38.0)$ & $30(15.0)$ & .66 \\
$\begin{array}{l}\text { During events, teachings, meetings received useful } \\
\text { information }\end{array}$ & $86(43.0)$ & $83(41.5)$ & $31(15.5)$ & .64 \\
$\begin{array}{l}\text { Got acquainted with various study programmes } \\
\begin{array}{l}\text { Found out about career possibilities after the acquisition } \\
\text { of the chosen speciality }\end{array}\end{array}$ & $75(37.5)$ & $95(47.5)$ & $30(15.0)$ & .61 \\
$\begin{array}{l}\text { Got useful advice making a career plan } \\
\text { (28.5) }\end{array}$ & $88(44.0)$ & $55(27.5)$ & .51 \\
& $36(18.0)$ & $110(55.0)$ & $54(27.0)$ & .46
\end{tabular}




\begin{tabular}{lcccc}
\hline \multicolumn{1}{c}{ Statements } & Agree & Partly agree & Do not agree & SI \\
\hline $\begin{array}{l}\text { Had a possibility (with the various diagnostic test } \\
\text { help) to evaluate one's own suitability for the chosen } \\
\text { profession }\end{array}$ & $43(21.5)$ & $92(46.0)$ & $65(32.5)$ & .45 \\
$\begin{array}{l}\text { Found out how to fill in the application in LAMA BPO } \\
\text { system }\end{array}$ & $53(26.5)$ & $70(35.0)$ & $77(38.5)$ & .44 \\
$\begin{array}{l}\text { Found out about the current situation in the labour } \\
\text { market and the profession demand }\end{array}$ & $31(15.5)$ & $112(56.0)$ & $57(28.5)$ & .44 \\
$\begin{array}{l}\text { Teachers introduced with their subject application in life } \\
\text { Found out how to write curriculum vitae (CV) }\end{array}$ & $45(22.5)$ & $83(41.5)$ & $72(36.0)$ & .43 \\
$\begin{array}{l}\text { Got support searching for voluntary activity during the } \\
\text { summer holidays }\end{array}$ & $38(19.0)$ & $75(37.5)$ & $87(43.5)$ \\
$\begin{array}{l}\text { Learnt to write a motivational letter to an employer } \\
\text { L }\end{array}$ & $24(12.0)$ & $79(39.5)$ & $97(48.5)$ & .32 \\
\hline
\end{tabular}

Analysing the obtained results, it was found out that the most useful information for the students was that they found out what subject exam results would be necessary in order to study the chosen profession $(S I=.73)$, found out about the entrance to vocational education institutions order and raised requirements $(S I=.66)$, during events, teachings, meetings received useful information $(S I=.64)$, got acquainted with various study programmes $(S I=.61)$. It is obvious that the obtained results show that the most actual information for the final grade gymnasium students was related to future studies at university, college or vocational school. For the respondents, the information was useful about career possibilities after acquisition the chosen profession $(S I=.51)$. However, the research results confirmed that students lacked information writing a motivational letter $(S I=.32$, searching for voluntary activity, a job during the summer holidays $(S I=.35)$, information writing CV $(S I=.38)$, LAMA BPO (Association of Lithuanian Higher Education Institutions for Joint Admission) system principles $(S I=.44)$, not sufficiently teachers introduced to their teaching subject application in life $(S I=.43)$. It turned out that the respondents did not have enough possibilities (with the various diagnostic test help) to evaluate their suitability for the chosen profession $(S I=.45)$, there was not enough information about the current situation in the labour market and profession demand $(S I=.44)$, received not enough useful advice making a career plan $(S I=.46)$.

During the research, the respondents' position was specified regarding lack of information choosing the profession. Students' answers allowed forming four categories: Information about professions, Information about studies, Information sufficiency, Self-cognition information (Table 3).

Table 3. Lack of information choosing the profession.

\begin{tabular}{|c|c|c|c|c|c|}
\hline Categories & $N(\%)$ & Subcategories & $N(\%)$ & Subcategory components & $N(\%)$ \\
\hline \multirow{5}{*}{$\begin{array}{l}\text { Information } \\
\text { about } \\
\text { professions }\end{array}$} & \multirow{5}{*}{$60(34.4)$} & \multirow{4}{*}{ Labour market } & \multirow{4}{*}{$\begin{array}{c}56 \\
(32.1)\end{array}$} & $\begin{array}{l}\text { Preparation for work (CV presentation, } \\
\text { motivational letter writing, preparation for an } \\
\text { interview) }\end{array}$ & $25(14.4)$ \\
\hline & & & & Profession supply and demand & $13(7.4)$ \\
\hline & & & & Specialists' good experience spread & $13(7.4)$ \\
\hline & & & & Personal benefit, payment & $5(2.9)$ \\
\hline & & $\begin{array}{l}\text { Professional } \\
\text { activity }\end{array}$ & $4(2.3)$ & $\begin{array}{l}\text { Activities in workplaces, visits to the } \\
\text { institutions }\end{array}$ & $4(2.3)$ \\
\hline
\end{tabular}




\begin{tabular}{|c|c|c|c|c|c|}
\hline Categories & $N(\%)$ & Subcategories & $N(\%)$ & Subcategory components & $N(\%)$ \\
\hline \multirow{4}{*}{$\begin{array}{l}\text { Information } \\
\text { about studies }\end{array}$} & \multirow{4}{*}{$58(33.0)$} & \multirow{2}{*}{$\begin{array}{l}\text { Information } \\
\text { about study } \\
\text { possibilities }\end{array}$} & \multirow[t]{2}{*}{$\begin{array}{c}46 \\
(26.3)\end{array}$} & $\begin{array}{l}\text { Study programme presentation, possibilities } \\
\text { to acquire the chosen profession, } \\
\text { acquaintance with the entrance order }\end{array}$ & $43(24.6)$ \\
\hline & & & & Study financing and state loans & $3(1.7)$ \\
\hline & & \multirow{2}{*}{$\begin{array}{l}\text { Preparation for } \\
\text { studies }\end{array}$} & \multirow{2}{*}{$\begin{array}{c}12 \\
(6.9)\end{array}$} & Exam choice, admission point calculation & $7(4.0)$ \\
\hline & & & & Application fulfilment LAMA BPO & $5(2.9)$ \\
\hline \multirow{2}{*}{$\begin{array}{l}\text { Information } \\
\text { sufficiency }\end{array}$} & \multirow{2}{*}{$\begin{array}{c}31 \\
(17.7)\end{array}$} & & \multirow{2}{*}{$\begin{array}{c}31 \\
(17.7)\end{array}$} & No lack of information & $23(13.1)$ \\
\hline & & & & Do not know & $8(4.6)$ \\
\hline \multirow{4}{*}{$\begin{array}{l}\text { Self-cognition } \\
\text { information }\end{array}$} & \multirow{4}{*}{$26(14.9)$} & \multirow{2}{*}{ Consultation } & \multirow{2}{*}{$\begin{array}{c}18 \\
(10.3)\end{array}$} & Consultation & $10(5.7)$ \\
\hline & & & & Individual consultation & $8(4.6)$ \\
\hline & & \multirow{2}{*}{ Self-cognition } & \multirow[b]{2}{*}{$8(4.6)$} & Self-cognition tests & $5(2.9)$ \\
\hline & & & & $\begin{array}{l}\text { Psychological tests about suitability for } \\
\text { profession }\end{array}$ & $3(1.7)$ \\
\hline
\end{tabular}

Note: 175 semantic units were distinguished

The first category Information about professions (34.4\%) had the biggest significance. It consisted of two subcategories: Labour market (32.1\%) and Professional activity (2.3\%). The results revealed that the students lacked information about preparation for work: $\mathrm{CV}$, motivational letter writing, preparation for an interview with an employer. One can make an assumption that students are interested more in employment possibilities after finishing school than possibilities to study further. The students lacked information about the profession demand, specialist's opinion would be important for them about a particular job, payment, there was a lack of workplace visits.

The second category Information about studies $(33.0 \%)$ according to its importance very little differed for the students from the first one. This category consisted of two subcategories: Information about study possibilities (26.3\%), Preparation for the studies (6.9\%). The results showed that a big part of students needed information about study programmes, study order, about possibilities to acquire a desired profession, study financing and a state loan. The students lacked information about exam choice, admission point calculation, application LAMA BPO fulfilment. This information was necessary for the students in order to study in a higher or vocational school. The obtained results allow making an assumption that students planning to further continue their studies and to acquire education and profession, lack this information.

The third category Information sufficiency (17.7\%) permitted to assert that choosing a career, the information was sufficient for not a big part of students.

The fourth category, according to its importance, Self-cognition information (14.9\%) showed that a small part of students lacked support cognising their features, their suitability for a certain profession. Therefore, the students desired individual consultations, self-cognition tests and so on.

Providing students with the help making future career choice, it was important to know what students' expectations were, what support demand was making a career choice. Students' answers allowed formulating four categories: Informational support, Sufficient support, Informational events, and Self-cognition support (Table 4). 
Table 4. Support demand choosing a profession.

\begin{tabular}{|c|c|c|c|c|c|}
\hline Categories & $N(\%)$ & Subcategories & $N(\%)$ & Subcategory components & $N(\%)$ \\
\hline \multirow{4}{*}{$\begin{array}{l}\text { Informational } \\
\text { support }\end{array}$} & \multirow{4}{*}{$\begin{array}{c}50 \\
(29.2)\end{array}$} & \multirow{2}{*}{$\begin{array}{l}\text { Information } \\
\text { about } \\
\text { professions }\end{array}$} & \multirow[t]{2}{*}{$32(18.8)$} & $\begin{array}{l}\text { Profession representative's provided } \\
\text { information }\end{array}$ & $21(12.2)$ \\
\hline & & & & Information about professions & $11(6.4)$ \\
\hline & & \multirow{2}{*}{$\begin{array}{l}\text { Information } \\
\text { about } \\
\text { preparation for } \\
\text { studies }\end{array}$} & \multirow{2}{*}{$18(10.6)$} & $\begin{array}{l}\text { Information about career planning, CV } \\
\text { preparation and motivational letter writing, } \\
\text { application writing LAMA BPO }\end{array}$ & $9(5.3)$ \\
\hline & & & & $\begin{array}{l}\text { Exam choice and entrance rule, admission } \\
\text { point calculation }\end{array}$ & $9(5.3)$ \\
\hline \multirow{3}{*}{$\begin{array}{l}\text { Sufficient } \\
\text { support }\end{array}$} & \multirow{3}{*}{$\begin{array}{c}50 \\
(29.2)\end{array}$} & Identified & \multirow{2}{*}{$33(19.3)$} & Enough information, receive enough & $17(9.9)$ \\
\hline & & support & & Do not need any & $16(9.4)$ \\
\hline & & $\begin{array}{l}\text { Undefined } \\
\text { support }\end{array}$ & $17(9.9)$ & Do not know & $17(9.9)$ \\
\hline \multirow{3}{*}{$\begin{array}{l}\text { Informational } \\
\text { events }\end{array}$} & \multirow{3}{*}{$\begin{array}{c}46 \\
(26.9)\end{array}$} & \multirow{2}{*}{$\begin{array}{l}\text { Visits to } \\
\text { institutions }\end{array}$} & \multirow[b]{2}{*}{$43(25.1)$} & Visits to the institutions, enterprises & $24(14.0)$ \\
\hline & & & & $\begin{array}{l}\text { Events, meetings, trips to higher and } \\
\text { vocational schools }\end{array}$ & $19(11.1)$ \\
\hline & & $\begin{array}{l}\text { Professional } \\
\text { activity }\end{array}$ & $3(1.8)$ & Work experience presentation & $3(1.8)$ \\
\hline \multirow{3}{*}{$\begin{array}{l}\text { Self-cognition } \\
\text { support }\end{array}$} & \multirow{3}{*}{$\begin{array}{c}25 \\
(14.7)\end{array}$} & \multirow{3}{*}{ Consultations } & \multirow{3}{*}{$25(14.6)$} & Self-cognition and profession suitability tests & $11(6.4)$ \\
\hline & & & & Profession choice, motivational conversations & $8(4.8)$ \\
\hline & & & & Individual consultations & $6(3.5)$ \\
\hline
\end{tabular}

Note: 171 semantic units were distinguished

The first category Informational support (29.2\%) and the second category Sufficient support (29.2\%) had equally important significance.

The first category Informational support (29.2\%) showed that students needed support, which could be profession representative's provided information. Students desired information about professions. Students indicated that they needed support getting information about preparation for studies: exam choice and entrance rules, admission point calculation, application writing LAMA $\mathrm{BPO}$. Students also needed support planning career, preparing $\mathrm{CV}$, motivational letter.

The second category Sufficient support (29.2\%) showed that support for the students was sufficient, they received enough information. However, it was mentioned that a part of the students $(9.9 \%)$ did not know what support they needed. One can make an assumption that these students accepted the given support indifferently, did not give attention to it.

The third, according to its importance, was the category Informational events (26.9\%). The content of this category revealed that visits to the institutions, enterprises, events, meetings, trips to higher and vocational schools, work experience would help the students to decide what profession to choose.

The fourth category Self-cognition support (14.7\%) was of the least importance. It is obvious that, students needed the least support cognising their features, their compatibility with the future profession.

Very often the surrounding environment and personal attitudes, hobbies and so on, have a big influence choosing a career. Therefore, the factors were analysed determining their career choice. The students' answers allowed to formulate three categories: External factors, Internal factors, Undefined factors (Table 5). 
Table 5. Factors having influence on career choice.

\begin{tabular}{|c|c|c|c|c|c|}
\hline Category & $N(\%)$ & Subcategory & $N(\%)$ & Subcategory components & $N(\%)$ \\
\hline \multirow{10}{*}{$\begin{array}{l}\text { External } \\
\text { factors }\end{array}$} & \multirow{10}{*}{$\begin{array}{c}97 \\
(49.5)\end{array}$} & \multirow{3}{*}{$\begin{array}{l}\text { Social } \\
\text { environment }\end{array}$} & \multirow{3}{*}{$46(23.5)$} & $\begin{array}{l}\text { Parents', teachers', friends' and close people } \\
\text { advice, opinion }\end{array}$ & $40(20.5)$ \\
\hline & & & & Social networks, press & $3(1.5)$ \\
\hline & & & & Conditions, society influence & $3(1.5)$ \\
\hline & & \multirow{4}{*}{ Labour market } & \multirow{4}{*}{$\begin{array}{c}34 \\
(17.4)\end{array}$} & Payment for the performed work & $16(8.2)$ \\
\hline & & & & Profession demand, popularity, necessity & $14(7.2)$ \\
\hline & & & & Work hours & $2(1.0)$ \\
\hline & & & & $\begin{array}{l}\text { Work character, place, work difficulty. } \\
\text { Improvement possibilities, prospects }\end{array}$ & $2(1.0)$ \\
\hline & & \multirow{3}{*}{$\begin{array}{l}\text { Informational } \\
\text { events }\end{array}$} & \multirow{3}{*}{$17(8.6)$} & $\begin{array}{l}\text { Lectures, meetings with alumni, specialist } \\
\text { advice }\end{array}$ & $7(3.6)$ \\
\hline & & & & Information about studies, professions & $6(3)$. \\
\hline & & & & Meetings with higher school representatives & $4(2.0)$ \\
\hline \multirow{3}{*}{$\begin{array}{l}\text { Internal } \\
\text { factors }\end{array}$} & \multirow{3}{*}{$\begin{array}{c}88 \\
(44.9)\end{array}$} & Personal features & $59(30.1)$ & $\begin{array}{l}\text { Personal choices, hobbies, inclinations, desires, } \\
\text { abilities }\end{array}$ & $59(30.1)$ \\
\hline & & \multirow[t]{2}{*}{ Progress } & \multirow[t]{2}{*}{$29(14.8)$} & $\begin{array}{l}\text { Grades, achievements, teachers' } \\
\text { encouragements, praise }\end{array}$ & $24(12.2)$ \\
\hline & & & & Final exam results & $5(2.6)$ \\
\hline \multirow{3}{*}{$\begin{array}{l}\text { Undefined } \\
\text { factors }\end{array}$} & \multirow{3}{*}{$\begin{array}{c}11 \\
(5.6)\end{array}$} & \multirow{3}{*}{$\begin{array}{l}\text { Non } \\
\text { informativeness }\end{array}$} & \multirow{3}{*}{$\begin{array}{c}11 \\
(5.6 \%)\end{array}$} & Do not have any affect & $5(2.6)$ \\
\hline & & & & Do not know & $4(2.0)$ \\
\hline & & & & Do not need information about professions & $2(1.0)$ \\
\hline
\end{tabular}

Note: 196 semantic units were distinguished

The first category External factors (49.5\%) which consists of three subcategories: Social environment (23.5\%), Labour market (17.4\%), Informational events ( $8.6 \%$ ) had the biggest significance. It is obvious that social environment: family, school, peer subculture, social networks, society had the biggest influence on students' career choice: Information about labour market: payment for carried out work, profession demand, popularity, necessity, working hours and the type, the place and work hardness, improvement possibilities and prospects, had a big influence on students making a career choice. Students thought that informational events, which were organised in the gymnasium: lectures, meetings with alumni, specialist advice, information about studies and professions, meetings with higher school representatives had a big influence on them choosing a profession.

The second category Internal factors $(44.9 \%)$ had a little less importance than the first category. A big part of students (30.1\%) defined that their personal features: personal choices, hobbies, inclinations, desires and abilities had a big influence on their career choice. Students' progress: grades, achievements, teachers' encouragement, praise doing various tasks, final exam results were of great importance choosing a career.

The third category Undefined factors (5.6\%) showed that not a big part of students could not identify what factors had influence on them choosing a career.

\section{Conclusions}

The carried-out research permits to state that gymnasium final grade students are provided with career education services: informational events take place, students are consulted, tests are performed, it is helped to cognise the working world, to cognise one's personality features and so on. The respondents know who can help them choosing a career, which specialist support they can hope for. Also, the activities are enumerated, which are the most useful and correspond to students' expectations. However, the results allow us to see a lack of provided information and support. 
Students' expressed expectations are not completely satisfied. Students lack knowledge about study programmes, profession specificity, CV preparation, motivational letter writing, LAMA BPO system fulfilment, individual consultations and other.

During the research, it was ascertained that gymnasium students planned their career, it was an actual problem for them. Research results showed that the bigger part of students understood professional career planning importance for their life quality, however they lacked information regarding this question. Only a small part of students thought that it was too early for them to plan their career, they were not planning it.

Research results revealed that most information about professions was provided for the students at schools during organised meetings with various profession representatives, during class hours, during the trip to higher school fair, during the trips to enterprises and institutions.

The research results allow stating that students perform self-cognition and profession suitability tests, which are useful for them and help in a career choice. Students also pointed out other useful activities making familiar to professions: meetings with former students, participation in various education institution organised open door days, individual consultations. However, a big part of the respondents thought that this information was not sufficient for them. One can claim that this information is necessary for students, they have expectations and questions to which they do not receive answers.

During the research, students' opinion was highlighted about career education activity usefulness choosing a profession. It was established that the most useful activities for gymnasium final grade students were related to information reception about future studies: what subject exam results will be necessary in order to study the chosen speciality, order of entrance to various institutions and raised requirements, the content of various study programmes.

During the research, the respondents' position was specified about a lack of information choosing the profession. It was stated that the students often lacked information about professions, labour market and study possibilities, preparation for studies. Therefore, students most often pointed out that choosing a profession, they needed informational support about professions, preparation for studies, informational events, self-cognition support.

\section{References}

Augienė, D., \& Lamanauskas, V. (2017). Magistrantūros studijų programa karjeros edukologija: modernus požiūris ị karjeros valdymą [Master's degree study programme career education: Modern position to career management]. Švietimas: politika, vadyba, kokybe / Education policy, Management and Quality, 9 (2), 98-106.

Bendrojo lavinimo mokyklu ir profesinio mokymo istaigu mokiniu ugdymo karjerai modelis [Model of career education for pupils in general education and vocational training institutions]. (2011). Vilnius: Vilniaus universiteto Specialiosios psichologijos laboratorija.

Dèl ugdymo karjerai programos patvirtinimo [Approval of the Career Education Program] (2014). Retrieved from https://e seimas.lrs.lt/portal/legalAct/lt/TAD/11018e70d00711e39b2ab5bbcc4f49fb.

Garniene, D. (2006). Bendrojo lavinimo mokyklos ugdymo karjerai modelis: parametrai ir realizavimo principai [Model of career education at general education school: parameters and realisation principles]. Summary of doctoral dissertation. Kaunas: Vytauto Didžiojo universiteto leidykla.

Indrašienė, V., Rimkevičienė V., Gaigalienė M., Railienė A., \& Grinytė L. (2006). Mokiniu profesinis informavimas, konsultavimas ir orientavimas mokykloje: tyrimo ataskaita [Vocational information, counseling and guidance for pupils: Study report]. Retrieved from https://www.smm.lt/uploads/documents/ kiti/prof_inf_paskut_paskutiniausias.pdf.

Juraitė, K., Laužackas, R., \& Pukelis, K. (2003). Moksleivių mobilumas: tolesnio mokymosi ketinimai ir jų ugdymo gairès [Mobility of pupils: intentions for further learning and guidelines for their development]. Profesinis rengimas: tyrimai ir realijos [Vocational Training: Research and Reality], 7, 62-71.

Kalinauskaite, R., Adaškevičienė, V., Tarnauskas, K., \& Žvirdauskas, D. (2005). Pasirinktu studiju ir mokykloje pasirinkto ugdymo turinio dermé: mokslinio tyrimo ataskaita [Coherence between selected studies and curriculum chosen at school: report on research]. Kaunas, 2005. 72 p. Retrieved from: http://www.elibrary.lt/inf_res4.phtml?id=7693. 
ISSN 2345-0193 (Print)

Baltic Journal of Career Education and Management

40
Renata VAITULIONIENĖ, Dalia AUGIENĖ. Career education implementation in gymnasium from the students' point of view

https://doi.org/10.33225/bjcem/18.6.30

Lietuvos valstybine švietimo 2013-2022 metu strategija [Lithuanian State Education Strategy 2013-2022] (2013). Retrieved from https:/www.sac.smm.lt/wp-content/uploads/2016/02/Valstybine-svietimostrategija-2013 2020_svietstrat.pdf.

Pečjak, S., \& Košir, K. (2007). Personality, motivational factors and difficulties in career decision-making in secondary school students. Psihologijske teme / Psychological Topics, 16(1), 141-158.

Received: October 22, 2018

Accepted: December 28, 2018

Renata Vaitulionienè

MSc., Career Education Specialist, Kalvarijos gymnasium, Lithuania.

E-mail: renvait@gmail.com

Dalia Augienè Ph.D., Senior Researcher at the University of Siauliai, Institute of Education,

P. Visinskio Street 25, LT-76351 Siauliai, Lithuania.

E-mail: augiene@gmail.com

Website: http://www.su.lt 